には油以外の膜面への付着物に対してはスポンジボー ルを用いて膜性能を一定以上に回復させている。化学 的洗浄，物理的洗浄が容易にでさるという点から管状 膜タイプがょく用いられる。

\section{2. アルミ不溶性塩の除去}

図 2 はアルミ表面処理浴中の不純物であるアルミ不 溶性塩をUF 装置を用いて連続的に除去し，透過水は ラインにもどし回収している $\mathrm{E}$ 社の例である。ここで は，浴が高温であるために耐熱性高分子管状膜を用い て成功している。UF 装置内は $\mathrm{SS}$ 濃度 $1,000 \mathrm{mg} \cdot \ell^{-1}$ 以 上であるために他の型式では不向きであった。この $\mathrm{UF}$ 設備の特徵は, 脱脂や水溶性切削油排水では, 透過 水量が $40 \sim 60 \ell \cdot \mathrm{m}^{-2} \cdot \mathrm{h}^{-1}$, 電着塗装 1 では $25 \sim 40 \ell \cdot \mathrm{m}^{-2}$ $\cdot \mathrm{h}^{-1}$, 活性污泥 ${ }^{2)}$ では $100 \sim 200 \ell \cdot \mathrm{m}^{-2} \mathrm{~h}^{-1}$ に対して, 高 温であることと液性状のために， $400 \sim 800 \ell \cdot \mathrm{m}^{-2} \cdot \mathrm{h}^{-1}$ と大きな透過水量を有していて装置がコンパクトになっ ていることである。目詰まり防止として，膜面に適当な 流速で液を供給することはもちろんのこと，定期的な 物理的洗浄 (スポンジボール) と化学的洗浄 (酸)に より性能を回復させている。スポンジボール洗浄は装 置を停止させることなしに連続運転中に行らことがで

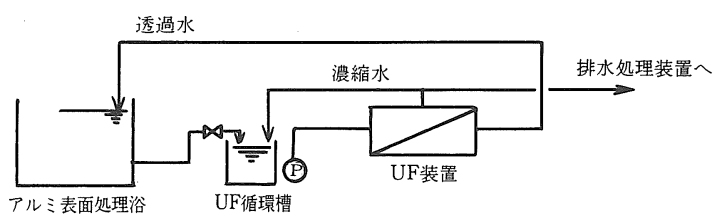

図2 $\mathrm{E}$ 社での有価物回収
きるメリットがある。

\section{3 . 半導体洗浄排水の微粒子除去}

上記の $1 ， 2$ は目に見党て多くの不純物を含む場合 であったため管状膜が用いられているが，MB 塔処理 後の純水中の微粒子の除去に対して単位容積当たりの 膜面積の多いキャピラリー型 (中空糸) が用いられる。 $\mathrm{F}$ 社は半導体の洗浄用純水を循環利用しているが, 微粒子の少ない純水を必要としている(図 3 参照)。 0.2 1 1 クロンの微粒子をほとんど完全に除去する には精密濾過 (MF) に上る方法が従来用いられてい たが非常にコストが高くつくことから UFまたは逆浸 透 $(\mathrm{RO})$ に上る膜分離が最近普及してきている。本装 置は定期的洗浄を必要とする活ど目詰をりはしない が，長期的には微粒子（注とんど死菌）によりわずか ずつ目詰まりするためアルカリ洗浄により透過水量を 回復させる方法をとっている。

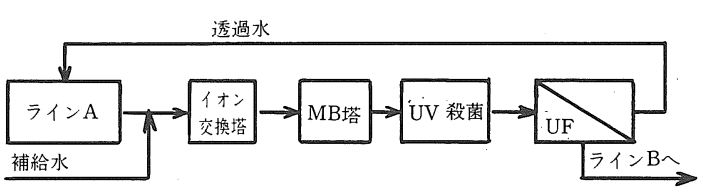

図 3 F 社での微粒子除去

\section{文献}

1 ) 兼松雅務 (1973) 電着塗装排水への膜利用とその問題点, 別 冊化学工業, 17, №. 7, 87 .

2 ）日笠勝（1985）限外ろ過膜を組み込んだ高濃度活性污泥法に よる排水処理, 用水と廃水, 27, №.10, 43 .

\title{
○食品加工排水*
}

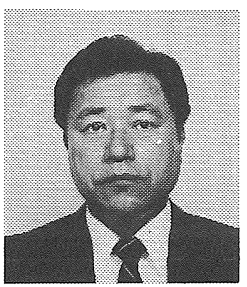

Satoshi Naruto

昭和34年 北海道大学卒業

同年 オルガノ秼

技術士（衛生工学部門）

〔趣味〕テニス

* The Application to Food Processing Wastewater, 昭和 61 年 12 月 5 日受理
鳴 戸 智

\section{1.はじめに}

食品工業に括ける膜利用については食品加工排水中 の有価成分を回収し再利用することと排水規制に対す る高度処理による排水の水質向上が期待される。さら に，膜利用によるエネルギー消費量の少ない効率的な 処理法としてその活用が注目されている。

こうした風潮に対して，農林水産省が産業振興政策 の 1 つとして食品加工排水を膜処理技術之嫌気性生物 処理を活用した新しい技術を造りあげる研究組合を指 
導してきている。官産学一体化を基調とした「食品産業 膜利用技術研究組合」は農林水産省の行政指導, 大学研 究室, 国立研究機関の研究指導のもとに食品会社, エン ジニアリング会社, 膜メーカーの 3 者により 3 年間に わたり多角的に，効率よく研究成果をあげることを意 図したものである。今後の成果が注目される。

研究の対象排水としてあげると, 澱粉糖排水, 洗糖蜜 排水, 製めん排水, イース卜製造排水等炭水化物を主対 象とするものと, 食肉加工排水, 水産加工排水, アミ， 酸排水，ミルク排水等蛋白質を対象とするものがある。

食品加工排水への膜処理の活用は民間ベースでの検 討子行われて扣り, 酪農加工排水, 澱粉加工排水, 水産 加工排水, 大豆蛋白排水, 製糖排水等に限外濾過 (UF ; Ultra filtration）膜を中心に実用化, 試験機運転が行 われている。

\section{2. 利用の現状技術}

欧米に打ける食品工業への膜利用は酪農分野を中心 に拡大してきたが，わが国に拀いては小規模ながら多 分野にわたって膜処理技術を進出させてきている。排 水処理での膜利用も同じょうにいろいろの食品につい て行っている。

\section{1 澱粉排水処理}

澱粉製造は, 原料を摩砝後, 澱粉とそれ以外の成分を 大量の水を用い遠心分離法により分離する。この工程 で出る高濃度の植物性蛋白や糖類等の有機成分を膜に より水と分離し，膜による有効成分を再利用する。

主成分は蛋白質と糖分であり馬鈴薯汁液では糖 0.4 0.7\%，蛋白質 $2.0 〜 2.5 \%$ となる。

膜は逆浸透（RO；Reverse Osmosis）のみで使用し 濃縮をする場合とUF と ROをシリーズで処理し高分子 量蛋白と低分子量蛋白に分画して濃縮する場合がある。

濃縮に際しては省エネルギー性の高い処理法である が, 反面, 膜の污染による急激な透過流束の低下が容易 に起きやすく,さらに, 微生物の繁殖しやすい液質のた め処理液水質の劣化と透過流束の低下をきたす。

これら問題点は洗浄法の工夫, 膜材質の選定により 適用化を位置づけている。

\section{2 水産加工排水処理}

スケトウダラ, イワシ等のスリミ加工に括いて, 加工 身に含まれる油分, 血, その他不純物を洗い出し, さら 乙操作を行う。さらし排水中には高い BOD, COD 値を 示す蛋白質が含まれている。また, 残渣物は煮熟加工を 行いフィッシュミールにするが, この加工工程ではさら し排水よりさらに高濃度の蛋白質が含まれるため（ス ティックウォーターと称する）この排水の処理が困難 である。
活性污泥処理による処理が行われるが，高蛋白質で あり,かつ, 濃度変動が急激に変わるため不具合になる 例が多い。高蛋白質をUF 膜で除去回収し，処理排水の 規制値遵守と回収蛋白質の再利用が検討されてきてい る。

\section{3 大豆蛋白加工排水}

大豆と水で蒸者し得られた蛋白質と酸凝固させ蛋白 カードをとりだす工程に扔いてホェーはそのまま排水 設備に流入する。

排水処理に対してUF 膜により高分子蛋白質の濃縮 をして回収する。さらに, UF 膜透過液中のオリゴ糖ミ ネラルは RO 膜により濃縮回収をする。 $\mathrm{RO}$ 膜の透過 液による排水水質として低 BOD 化が可能である。 これにより排水処理設備への負荷を高めることができる。 味曾工場の排水では大豆蒸煮処理排水が $80 \%$ 以上を 占める。その処理については $\mathrm{RO}$ 膜により大豆蛋白の 濃縮（15 12Bx）回収する。一方, 透過液は大豆浸せ き液として水回収再利用が行われる。

\section{4 製糖工場排水処理}

洗糖工程から脱色, 濃縮, 結晶化に揖いて, 濾過機骨 炭塔，イオン交換塔での水洗による Bx 1 2 2までの 含糖液は甘水として RO 膜による濃縮が実施される。

$\mathrm{Bx} 1$ 以下の含糖排水も排水処理装置に入る前に $\mathrm{RO}$ 膜による濃縮回収により膜透過水の COD 低減が 認められている。

糖液の希釈によりバクテリアの繁殖が起こりやす く, その処理については殺菌方法を工夫していくこと が必要である。

\section{3 . 膜について}

食品工業に用いられる膜は対象液が高濃度, 高粘度 の液性であり, かつ, 腐敗を極度に避けるため膜モ ジュールの構造に残存物が出にくい上らにしておく か, 洗浄が容易になっていることが必要になる。さらに は, 各種殺菌剂の使用濃度に十分耐兄られる膜モ ジュール材質であることも使用条件として必要であ る。

膜モジュールの種類はプレート・アンド・フレーム, 管状，スパイラル状の膜モジュール構造を持ったUF 膜, $\mathrm{RO}$ 膜となる。これら膜モジュールはデッドスペー スを可能な限りなくすと共に, 膜面流速を過剰に流す ことができる構造であることが必要である。

最近では, 供給圧 $15 \mathrm{~kg} / \mathrm{cm}^{2}$ 以下の低圧 $\mathrm{RO}$ 膜の開発 が活発化して拉り, 省エネルギーの面とこの膜特性で ある食塩除去率が $90 \%$ 以下であることを利用して高分 子有価物質と共存塩類との分離に活用されている。 


\section{4 . 膜機能の変化と回復}

膜機能の変化を大別すると透過流束の低減と分離機 能の変化となる。この原因は目詰まりと濃度分極, ゲル 層形成と考兄られる。目詰まりについては膜表面のス キン層の孔径が影響し, 食品の溶質のように分子量の 小から大までの広範囲分子量分布の溶液では UF 膜の よらなものは目詰まり現象は起こりやすい。濃度分極, ゲル層形成は低分子，高分子分子量の溶質の存在下で 派生してくるが主としてゲル層形成が大きな因子と考 える。食品工場の排水の場合, ゲル層形成による膜機能 の低下原因としてクローズアップされる。

\section{1 ゲル層形成による膜機能の变化}

ゲル層の形成の現象は透過流束が低減してきて,や がて一定流量に固定化されるようになる。その低下率 は対象液により異なるが $1 / 2 \sim 1 / 10 か ゙$ 通常みられる。 た，分離機能にしても，UF 膜を例にとると，使用する 膜の分子量分画からみて明らかに透過する分子量を持 つ対象物質が高分子量物質のゲル層形成により同時に 膜面に捕捉され本来の分離処理ができなくなる。

ゲル層形成については密な膜ほど除去しやすいゲル 層を生成し粗な膜ほど除去しにくいゲル層が形成され る。また,ゲル層の形成については膜面流速を早くとる ことにより形成を阻止することができる。反面,一度ゲ ル層ができるとなかなか除去できにくい。ゲル層は低 流速で形成されるが除去するのも容易である。

こうしたことから，ゲル層の形成について透過流速 に対する抵抗の少ない透過条件を定め,かつ, 適した洗 浄法によりゲル層の形成排除による透過流量の回復を もたらす。

洗浄法については次の方法がとられている。

（1）物理的手法

(a) 逆洗法

透過流束の低下が一定值に達した時点で圧力を下げ ると透過液が逆流し，目詰まり物質あるいはゲル層を 洗い落とすことができる。図 1 に一例を示す。

(b) スポンジボール洗浄法

円管型モジュール内にスポンジボールを流し，ボー ル表面で膜面表面をこするようにして除去する。

(c) 乱流促進洗浄法

膜の形状から乱流促進機構で流れを乱すように洗浄 流量, 圧力を変えて除去するようにする。

(2) 化学的手法

次亜塩素酸ナトリウムの有機物分解力や水酸化ナト リウムによる薬剤処理が回復洗浄法として用いられ

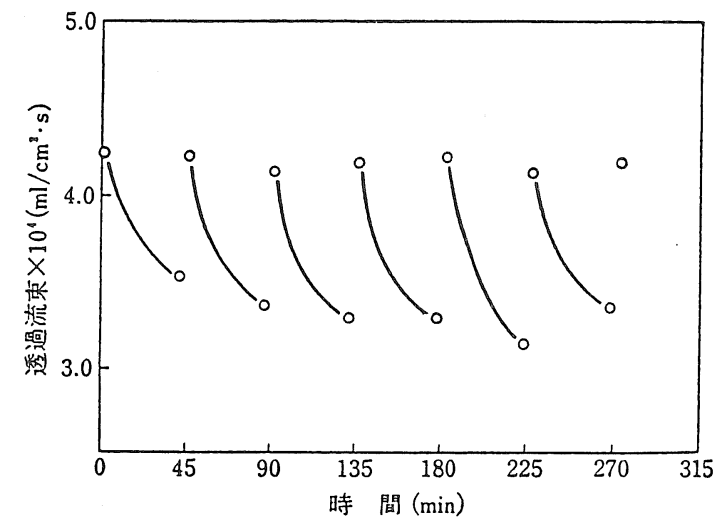

図 1 膜面付着物による透過流束の低下拉よび洗浄による 透過流束の回復 2

タンク圧力： $30 \mathrm{~kg} / \mathrm{cm}^{2}$, 洗浄時間：10 秒.

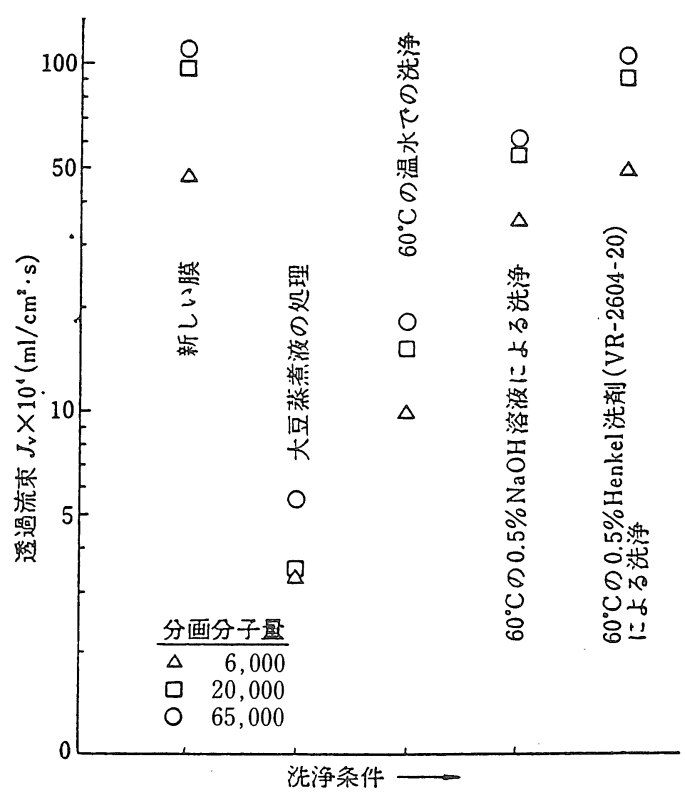

図 2 各種洗浄法による透過流束の回復（納豆製造におけ る大豆蒸煮液の $\mathrm{UF}$ 処理 ${ }^{3}$

る。図 2 にその効果の一例を示す。

\section{文献}

1）食品工業と膜利用, 幸書房, p.52.

2) 食品工業之膜利用, 幸書房, p.63.

3 ）食品工業之膜利用, 幸書房, p.73. 